\title{
Rehabilitation in Children With Sclerodermoid Chronic Graft-Versus-Host Disease: Case Series
}

\author{
Minji Jung, MD, In Young Sung, MD, PhD, Eun Jae Ko, MD, PhD
}

Department of Rehabilitation Medicine, Asan Medical Center, University of Ulsan College of Medicine, Seoul, Korea

Joint contracture in chronic graft-versus-host disease (cGVHD) is refractory to treatment, and tends to deteriorate gradually over time. There is scant clinical research focusing on timing and intensity of rehabilitation on joint contractures in children with sclerodermoid cGVHD after hematopoietic stem cell transplantation. We retrospectively reviewed rehabilitative therapeutic effects in 6 children with sclerodermoid cGVHD, whose clinical records documented their condition, before and after rehabilitation therapies. Three children who started treatment within a mean of 2 months after the onset of joint symptoms, and who underwent home-based exercise twice daily for 30 minutes showed more prominent improvement in range of motion compared with the other 3 children, who started rehabilitation therapy later than 6 months after onset of joint symptoms, without regular home-based exercise.

Keywords Graft vs host disease, Joint contracture, Rehabilitation

\section{INTRODUCTION}

Allogeneic hematopoietic stem cell transplantation (HSCT), has been performed to treat many hematologic diseases. Acute and chronic graft-versus-host disease (GVHD) are multisystem disorders that are common complications of allogeneic HSCT. Chronic GVHD (cGVHD) is the most common long-term complication after allogeneic HSCT; and is a major cause of late morbidity that impairs quality of life and function [1]. While acute GVHD is driven mainly by mature donor T cells, cGVHD involves a more complex immune reaction with
$\mathrm{T}$ and $\mathrm{B}$ cells contributing to underlying pathology [2]. Although donor antibodies to recipient antigens play a role in cGVHD, exact mechanisms of how these cells contribute to underlying pathology are being investigated. BAFF is a key regulator of B-cell homeostasis, and high levels have been shown to rescue self-reactive B cells from peripheral deletion [3] promoting survival and differentiation.

Among the symptoms of cGVHD, sclerodermoid GVHD (ScGVHD) is a major risk factor for joint contractures and related pain and dysfunction, and results from inflammation and fibrosis (Fig. 1) of the dermis, subcutaneous tis-

Received July 27, 2018; Accepted September 27, 2018

Corresponding author: In Young Sung

Department of Rehabilitation Medicine, Asan Medical Center, University of Ulsan College of Medicine, 88 Olympic-ro 43 gil, Songpa-gu, Seoul 05505, Korea. Tel: +82-2-3010-3800, Fax: +82-2-3010-6964, E-mail: iysung56@gmail.com

ORCID: Minji Jung (http://orcid.org/0000-0002-4104-7353); In Young Sung (http://orcid.org/0000-0001-6545-6744); Eun Jae Ko (http://orcid.org/00000001-7198-5407).

(c) This is an open-access article distributed under the terms of the Creative Commons Attribution Non-Commercial License (http://creativecommons.org/ licenses/by-nc/4.0) which permits unrestricted noncommercial use, distribution, and reproduction in any medium, provided the original work is properly cited. Copyright ( 2019 by Korean Academy of Rehabilitation Medicine 



Fig. 1. Appearance of the affected extremities in patient with sclerodermoid chronic graft-versus-host disease.

Table 1. Characteristics of children with sclerodermoid cGVHD

\begin{tabular}{cccccccc}
$\begin{array}{c}\text { Case } \\
\text { no. }\end{array}$ & Sex & Diagnosis & $\begin{array}{c}\text { Type of } \\
\text { HSCT }\end{array}$ & $\begin{array}{c}\text { Age at } \\
\text { HSCT } \\
\text { (yr;mo) }\end{array}$ & $\begin{array}{c}\text { Age at ScGVHD } \\
\text { symptom onset } \\
\text { (yr;mo) }\end{array}$ & $\begin{array}{c}\text { Age at lst } \\
\text { rehabilitation } \\
\text { intervention (yr;mo) }\end{array}$ & $\begin{array}{c}\text { Interval between symptom* } \\
\text { onset and rehabilitation } \\
\text { intervention (day) }\end{array}$ \\
\hline 1 & F & JML & Allo PBSCT & $5 ; 6$ & $7 ; 5$ & $7 ; 7$ & 49 \\
2 & M & CGD & Allo PBSCT & $4 ; 2$ & $5 ; 6$ & $5 ; 9$ & 72 \\
3 & F & AML & Auto PBSCT & $1 ; 4$ & $2 ; 8$ & $2 ; 10$ & 55 \\
4 & M & AML & Allo PBSCT & $3 ; 1$ & $4 ; 2$ & $4 ; 9$ & 194 \\
\hline 5 & F & ALL & Allo PBSCT & $11 ; 0$ & $3 ; 4$ & $4 ; 1$ & 270 \\
\hline 6 & F & JML & Allo PBSCT & $1 ; 0$ & $1 ; 10$ & $2 ; 4$ & 180 \\
\hline
\end{tabular}

cGVHD, chronic graft-versus-host disease; HSCT, hematopoietic stem cell transplantation; ScGVHD, sclerodermoid GVHD; JML, juvenile myelomonocytic leukemia; CGD, chronic granulomatous disease; ALL, acute lymphatic leukemia; AML, acute myeloid leukemia; PBSCT, peripheral blood stem cell transplantation; symptom*, ScGVHD symptom.

sue, or fascia [2]. Clinically, sclerodermatous GVHD often shows a rippled skin appearance, whereas fasciitis may present with stone-like tightness on palpation and lucidity of overlying skin. In histopathological examinations of fasciitis, oedema and fibrosis are confined to the fasciae and subcutaneous septa with entrapment of subcutaneous fat and a pericapillary lymphoplasmacellular infiltrate [4]; these changes result in reduced range of motion (ROM), and significant loss of strength and functional capabilities.

Although ScGVHD is a disabling disease causing functional impairment and decreased quality of life, there are no studies addressing the critical nature of early initiation of rehabilitation therapy or home-based exercise [5]. Hence, we illustrate the critical nature of timing of rehabilitative intervention after symptom onset in children with ScGVHD, and the importance of regular homebased exercise.

\section{CASE REPORTS}

According to medical records of the Asan Medical Center of Seoul, Korea, 91 pediatric patients (younger than age 18) diagnosed with cGVHD, were referred to the Department of Rehabilitation Medicine, Division of Pediatric Rehabilitation Medicine for rehabilitation therapy 1997-2017. Among them, we identified 6 children affected by ScGVHD after HSCT, for whom we identified preand post-rehabilitation therapy assessments. Average age of the study population was 5.8 years, when rehabilitation was first initiated. Diagnoses and joints affected are presented in Tables 1 and 2 . These 6 children with significant joint contractures participated in a rehabilitation therapy program, including physical therapy such as stretching exercises to improve ROM and occupational therapy to increase ROM and prevent disuse atrophy. We provided an education session for the parents to teach them how to continue stretching their children's affected joints.

Three of the children showed significant improvement, 
Table 2. Range of motion in involved joints and rehabilitation therapy

\begin{tabular}{|c|c|c|c|c|c|c|}
\hline \multirow{2}{*}{$\begin{array}{c}\text { Case } \\
\text { no. }\end{array}$} & \multirow[b]{2}{*}{ Joint } & \multirow[b]{2}{*}{ Movement } & \multicolumn{2}{|c|}{$\operatorname{ROM}\left({ }^{\circ}\right)$} & \multirow{2}{*}{$\begin{array}{c}\text { Intensity and duration } \\
\text { of rehabilitation } \\
\text { therapy by therapists }\end{array}$} & \multirow{2}{*}{$\begin{array}{c}\text { Home-based } \\
\text { ROM exercise } \\
\text { by parents }\end{array}$} \\
\hline & & & $\begin{array}{c}\text { Pre-rehabilitation } \\
\text { intervention }\end{array}$ & $\begin{array}{c}\text { Post-rehabilitation } \\
\text { intervention }\end{array}$ & & \\
\hline 1 & Rt. elbow & Extension & -50 & -30 & $\begin{array}{l}\text { Five sessions of thera- } \\
\text { py, for } 1 \text { week, every } \\
30 \text { minutes }\end{array}$ & $\begin{array}{c}\text { Twice a day, } 30 \mathrm{~min} \\
\text { utes for } 1 \text { week }\end{array}$ \\
\hline \multirow[t]{3}{*}{2} & Rt. wrist & Extension & 30 & 75 & $\begin{array}{l}\text { One session of parents } \\
\text { education, } 30 \mathrm{~min} \text { - } \\
\text { utes }\end{array}$ & $\begin{array}{c}\text { Twice a day, } 30 \mathrm{~min} \\
\text { utes for } 2 \text { weeks }\end{array}$ \\
\hline & Lt. wrist & Extension & 25 & 45 & & \\
\hline & Both MCP & Flexion & 15 (Rt.), 60 (Lt.) & 75 (Rt.), 75 (Lt.) & & \\
\hline \multirow[t]{5}{*}{3} & Rt. wrist & Extension & -30 & 75 & $\begin{array}{l}\text { One session of parents } \\
\text { education, } 30 \text { min- } \\
\text { utes }\end{array}$ & $\begin{array}{l}\text { Twice a day, } 30 \mathrm{~min} \\
\text { utes for } 7 \text { months }\end{array}$ \\
\hline & Lt. wrist & Extension & -30 & 65 & & \\
\hline & Both 2nd PIP & Extension & -20 (Rt.), -10 (Lt.) & 0 (Rt.), 0 (Lt.) & $\begin{array}{l}\text { One session of parents } \\
\text { education, } 30 \mathrm{~min} \text { - } \\
\text { utes }\end{array}$ & $\begin{array}{l}\text { Twice a day, } 30 \mathrm{~min} \\
\text { utes for } 16 \text { months }\end{array}$ \\
\hline & Both 3rd PIP & Extension & -25 (Rt.), -20 (Lt.) & 0 (Rt.), - 13 (Lt.) & & \\
\hline & Both 4th PIP & Extension & -25 (Rt.), -20 (Lt.) & 0 (Rt.), -8 (Lt.) & & \\
\hline 4 & Lt. ankle & Dorsiflexion & -20 & $-20^{\circ}$ & $\begin{array}{l}\text { Weekly based therapy } \\
\text { session, } 30 \text { minutes } \\
\text { for } 13 \text { months }\end{array}$ & $\begin{array}{l}\text { Twice a week, } 10- \\
15 \text { minutes for } 13 \\
\text { months }\end{array}$ \\
\hline 5 & Both ankles & Dorsiflexion & 0 (Rt.), 0 (Lt.) & 10 (Rt.), 10 (Lt.) & $\begin{array}{l}\text { Weekly based therapy } \\
\text { session, } 30 \text { minutes } \\
\text { for } 3 \text { monthsz }\end{array}$ & - \\
\hline 6 & Both MCP & Flexion & 60 (Rt.), 60 (Lt.) & 70 (Rt.), 65 (Lt.) & $\begin{array}{l}\text { Weekly based therapy } \\
\text { session, } 30 \text { minutes } \\
\text { for } 40 \text { months }\end{array}$ & - \\
\hline
\end{tabular}

ROM, range of motion; MCP, metacarpophalangeal joint; PIP, proximal interphalangeal joint.

while the other three did not show significant improvement or change in ROM. The differences depended on the time to initiate rehabilitation after ScGVHD, and intensity of home-based exercise. Three children who started treatment within a mean of 2 months after the onset of joint symptoms, and who underwent home-based exercise twice a day for 30 minutes, showed more prominent improvement in ROM, compared with the other 3 children who started rehabilitation therapy later than 6 months after the onset of joint symptoms without regular home-based exercise.

\section{Case 1, 2, and 3}

Characteristics of children are presented in Table 1. They were referred to clinic for rehabilitation therapy mean 58.6 days ( 49 days for case 1, 72 days for case 2, and
55 days for case 3) after their symptoms of joint contracture were diagnosed. We instructed the parents to exercise their child, twice a day for 30 minutes. In the case 1 child, after five sessions of rehabilitation therapy and home-based exercise including ROM exercise, her elbow extension surprisingly improved to $-30^{\circ}$ on the right (Figs. $2,3)$. In the case 2 child, after faithfully maintaining the home exercise program. Surprisingly, the right wrist extension angle improved by $75^{\circ}$ and the right MCP joint flexion also improved by $75^{\circ}$ after only 2 weeks of passive ROM exercise. In the case 3 child, the joint contractures on both wrists and right PIP joints improved to completely normal from intensive and active home-based exercise of the wrists for 7 months and of the IP joints for 16 months. 


\section{Case 4, 5, and 6}

Characteristics of children are presented in Table 1. They were referred to clinic for rehabilitation therapy mean 214.6 days (194 days for case 1, 270 days for case 2 , and 180 days for case 3 ), after their symptoms of joint contracture were diagnosed. They did not show significant improvement in ROM home-based exercise. They were treated at the hospital for 30 minutes once a week, and treatment duration varied from 3 months for case 5 to 40 months for case 6 . Home-based exercise therapy was not performed due to lack of parental cooperation.

\section{DISCUSSION}

Although effectiveness of rehabilitation therapy has been reported, it is the first study to confirm effectiveness of rehabilitation according to the timing of rehabilitation after ScGVHD symptom onset in children younger than age 10. Although this is not a case control study, degree of improvement in ROM was significantly greater than a previous study [5] in patients who underwent rehabilitation treatment within a mean of 60 days after ScGVHD symptom onset. Those results may due to applying intensive rehabilitation before the onset of definite joint contracture and regular home-based exercise twice daily.

Physical rehabilitation in cGVHD can facilitate restoration of musculoskeletal system function, which would allow patients to retain some mobility and independence [6]. Once a contracture has developed active and passive ROM exercises with sustained stretch at least twice

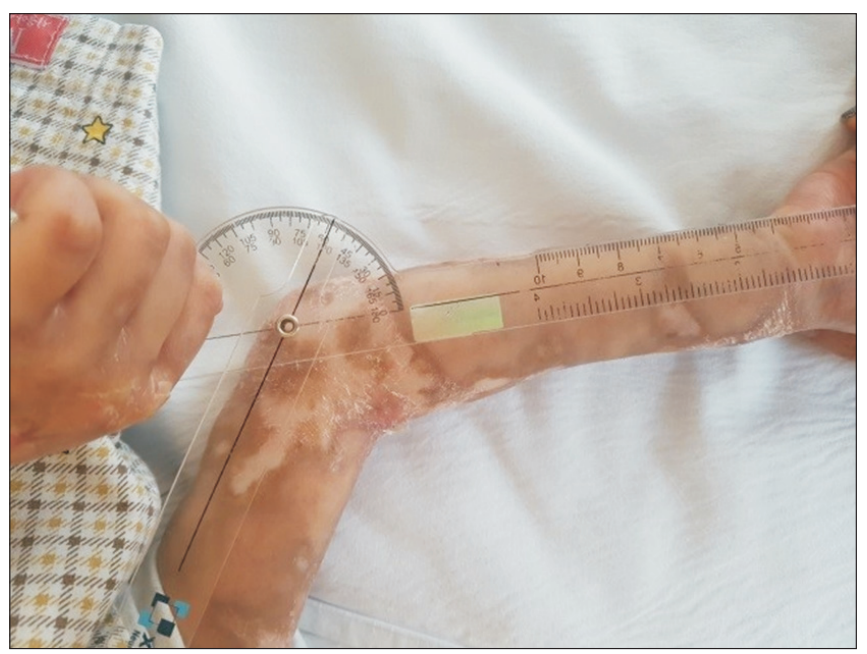

Fig. 2. Elbow joint contracture at the first assessment. daily are necessary [7]. Home-based exercise is essential to perform frequent joint exercises, and it is crucial for parents to conduct regular joint range exercise to prevent joint contracture [8].

In terms of immunosuppressive agents and steroids, standard initial therapy of cGVHD is prednisone with or without a calcineurin inhibitor, although only approximately $50 \%$ of persons have durable response [9]. Immunosuppressive agents including sirolimus, tacrolimus, mycophenolate, methotrexate are recommended but poorly standardized as standard next therapy [10]. There were only drugs continuously used before ScGVHD symptom manifestation without adding or increasing dosage during rehabilitation therapy (Table 2).

ScGVHD may have lengthy contracting duration with progressive sclerotic changes and cause multiple joint contractures. Therefore, we suggest that ScGVHD patients are managed with aggressive rehabilitation therapy from onset of the illness and maintain therapy for an extended time to restore joint ROM as well as prevent progression to permanent joint contracture. Additionally, regular home-based stretching exercise performed by parents is a key factor in reducing joint stiffness. In conclusion, early rehabilitation therapy and faithful homebased exercise for patients with ScGVHD after HSCT is effective for improving joint ROM.

\section{CONFLICT OF INTEREST}

No potential conflict of interest relevant to this article

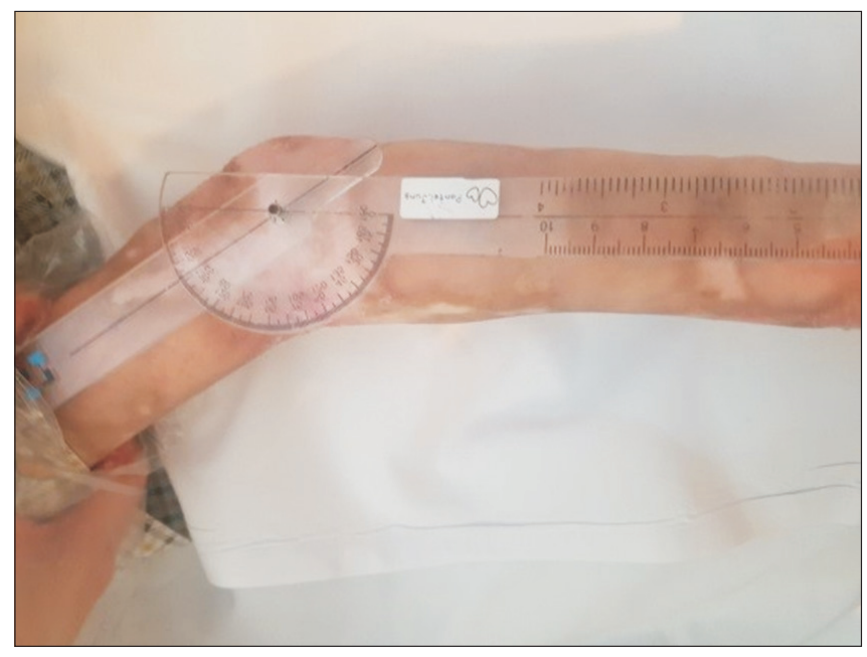

Fig. 3. Improved elbow joint contracture after five sessions of therapy. 
was reported.

\section{AUTHOR CONTRIBUTION}

Conceptualization: Jung M, Sung IY, Ko EJ. Methodology: Jung M, Sung IY. Formal analysis: Jung M. Project administration: Sung IY. Visualization: Jung M. Writing original draft: Jung M. Writing - review and editing: Sung IY. Approval of final manuscript: all authors.

\section{REFERENCES}

1. Nanda A, Husain MA, Al-Herz W, Almekaimi A, Al-Sabah $\mathrm{H}, \mathrm{Al}$-Otaibi M. Chronic cutaneous graft-versus-host disease in children: a report of 14 patients from a tertiary care pediatric dermatology clinic. Pediatr Dermatol 2018;35:343-53.

2. Lee SJ, Flowers ME. Recognizing and managing chronic graft-versus-host disease. Hematology Am Soc Hematol Educ Program 2008;2008:134-41.

3. Thien M, Phan TG, Gardam S, Amesbury M, Basten A, Mackay F, et al. Excess BAFF rescues self-reactive B cells from peripheral deletion and allows them to enter forbidden follicular and marginal zone niches. Immunity 2004;20:785-98.

4. Marks C, Stadler M, Hausermann P, Wolff D, Buchholz S, Stary G, et al. German-Austrian-Swiss Consensus Conference on clinical practice in chronic graft- versus-host disease (GVHD): guidance for supportive therapy of chronic cutaneous and musculoskeletal GVHD. Br J Dermatol 2011;165:18-29.

5. Carenzio G, Gherardi P, Bardoni MT, Zecca M, Bonetti F, Locatelli F, et al. Rehabilitation of chronic graft versus host disease in children: a clinical series. Eura Medicophys 2007;43:445-50.

6. Mohammed J, Savani BN, El-Jawahri A, Vanderklish J, Cheville AL, Hashmi SK. Is there any role for physical therapy in chronic GvHD? Bone Marrow Transplant 2018;53:22-8.

7. Halar EM, Bell KR. Immobility and inactivity: physiological and functional changes prevention and treatment. In: DeLisa JA, Gans BM, Walsh NE, editors. Physical medicine and rehabilitation: principles and practice. Philadelphia: Lippincott Williams \& Wilkins; 2004. p. 1447-67.

8. Tendas A, Boschetto C, Baraldi L, Caiazza E, Cupelli L, Lentini $\mathrm{R}$, et al. Homecare-based motor rehabilitation in musculoskeletal chronic graft versus host disease. Indian J Palliat Care 2011;17:159-61.

9. Deeg HJ. How I treat refractory acute GVHD. Blood 2007;109:4119-26.

10. Koreth J, Matsuoka K, Kim HT, McDonough SM, Bindra B, Alyea EP 3rd, et al. Interleukin-2 and regulatory T cells in graft-versus-host disease. $\mathrm{N}$ Engl J Med 2011;365:2055-66. 